Article

\title{
Analyses of Waste Treatment in Rural Areas of East Java with the Possibility of Low-Pressure Briquetting Press Application
}

\author{
Pavla Fajfrlíková ${ }^{1}$, Anna Brunerová ${ }^{2}$ (D) and Hynek Roubík ${ }^{3, * \mathbb{C}}$ \\ 1 Faculty of Economics and Management, Czech University of Life Sciences Prague, Kamýcká 129, \\ 16500 Prague, Czech Republic; fajfrlikova@pef.czu.cz \\ 2 Faculty of Engineering, Czech University of Life Sciences Prague, Kamýcká 129, 16500 Prague, \\ Czech Republic; brunerova@tf.czu.cz \\ 3 Faculty of Tropical AgriSciences, Czech University of Life Sciences Prague, Kamýcká 129, 16500 Prague, \\ Czech Republic \\ * Correspondence: roubik@ftz.czu.cz
}

Received: 3 August 2020; Accepted: 1 October 2020; Published: 2 October 2020

\begin{abstract}
The study deals with the possibility of waste utilization by using briquetting technology (production of solid fuels) and the potential of the manual low-pressure briquetting press in rural and peri-urban areas of East Java, where firewood is still commonly used as a source of energy for heating and cooking (besides LPG). The research compares households from the Donowarih village (Malang regency) and from the Maron peri-urban area (Blitar regency). Through quantitative and qualitative research, we document the potential of briquette production from household waste and agriculture production. The population from the peri-urban area is interested and willing to invest more in the technology, even though a higher biomass production has been found in the rural area. Financial possibilities were similar in both areas $(p=0.8986)$. A positive correlation $(R=0.5146)$ was found between the level of education and level of potential investments. Thus, higher education level meant higher interest in technology and the willingness to invest in it. In both areas there is a potential for briquette production and demand for its usage. Nevertheless, further research is recommended to find the suitable composition of bio-briquettes after the installation of wooden manual low-pressure briquetting press.
\end{abstract}

Keywords: biomass; waste management; bio-briquettes; renewable energy sources; developing countries

\section{Introduction}

Until today, coal and natural gas have played important roles in producing the world's electricity. However, with the limitation of resources and the greenhouse effect, renewable energy is becoming more popular as a suitable alternative, which consequently mitigates climate change and enhances energy security. Renewable energy sources are derived from natural, thermal, mechanical, and growth processes that repeat themselves within our lifetime and may be relied upon to produce predictable quantities of energy when needed. Therefore, renewable energy sources can be infinitely available [1].

Renewable energy started to be important also in the case of Indonesia. Indonesia's economy has been on the rise in recent decades, as has the demand for energy sources. The largest energy consumption is attributable to transport and industry; households contribute around 20\% [2]. Taking into account the fact that Indonesia ranks fourth in terms of the world's population, primary energy consumption can significantly affect the world's energy consumption. Indonesia has been a member of OPEC several times, mainly due to its oil and natural gas reserves [3]. With rising consumption, 
however, supplies are gradually becoming thinner, and demand for other energy sources is increasing. Recently found coal deposits mainly in Sumatra and Kalimantan can partly fulfil the demand; on the other hand, large areas including rainforest are disappearing, and mining is causing irreversible damage to the environment [4]. Indonesian authorities are aware of this problem; therefore, the government of Indonesia stipulated the target of producing $17 \%$ of its energy supply from renewable energy sources by 2025 [5].

In Indonesia, renewable energy from biomass is currently the third most important energy source which can be utilized for heat and electricity production. Sources like forestry, agriculture, or food residues are mostly used for its production. According to Mulyana et al. [6], it is more efficient to convert biomass into some of the following forms: solid biofuels (briquettes, pellets), liquid biofuels (ethanol, biodiesel, methanol, etc.), or gaseous biofuels (methane, hydrogen, carbon monoxide), making its use more effective while eliminating negative environmental impacts. These biofuel energy sources are also easy to store and transport.

As for renewable energy, Indonesia is well known especially for liquid biofuel conversion. It is one of the largest producers of bioethanol and biodiesel in the Asian region [7]. Indonesia's biofuels program is focused on palm oil-based biodiesel. There is no fuel ethanol production in Indonesia; however, there are 14 ethanol plants producing nonfuel ethanol (mostly from molasses) for the medical industry, cosmetics, and for export [8]. Unfortunately, due to large-scale palm tree plantations, Indonesia is facing a risk of deforestation or food security issues [9]. Palm oil plantations have already covered large areas in major islands such as Kalimantan, Sulawesi, and Papua [10].

\section{Waste to Energy}

On the one hand, liquid conversion of biomass can successfully solve the growing demand for energy; on the other hand, it cannot solve another emerging problem, which is Indonesian waste management issues. With increasing population and urbanization, there is also a need for adequate waste management. Unfortunately, the country does not have sufficient experience in this matter [11,12]. The environment is mainly polluted by industrial, agricultural, and communal waste [13]. Waste treatment in Indonesia mostly consists of its accumulation in landfills (often unauthorized) or its direct unprofitable incineration. This waste burning (mostly agricultural or communal) contributes to environmental pollution. One possible solution to help mitigate the effects is the usage of the organic waste material as an energy source. The conditions for the use of biomass in Indonesia are more than favorable, as agricultural organic material is produced at around 250 billion tons per year [14]. In the case of municipal waste, the bigger part consists of organic waste, such as kitchen leftovers from households. At present, the waste is either burned at each household or collected by the municipalities and later dumped into a designated dumping ground or landfill. Although the government provides facilities to collect and clean all this waste, the growing population, an inadequate number of waste treatment facilities, along with an inadequate budget allocated for waste management have led to most of the large cities in Indonesia suffering from the increasing problem of waste disposal and the resulting pollution and health issues [15,16]. An estimated 900 tons of methane gas (greenhouse gas) from all landfills in Indonesia are spread into the air each year [17]; such emissions could be significantly reduced, or potentially even used as an energy recovery source [18].

One of the options that could positively contribute to both more sustainable energy production and sustainable waste management is the so-called "waste to energy" methods. One of those methods is the processing of biomass into solid biofuels. The use of biomass for direct combustion still supports the basic requirements for energy consumption in heating and cooking in rural areas of developing countries $[19,20]$. According to Demirbas [1], predominantly low-income biomass is still used in cooking or smaller plants. The current pressure on cost savings and competitiveness in Indonesia's most important biomass-based industries, along with the continually growing power demands of the country, signal opportunities for increased exploitation of biomass waste for power generation. According to Prastowo [21], the estimated total energy that can be obtained from agricultural residues 
in Indonesia is 614 million GJ/year, and that from forestry residues can reach 141 million GJ/year. However, the utilization of biomass as the energy source also contributes to forest destruction [22] and creates conflicts about land use [1]. On the other hand, the use of briquette biofuel from agricultural residues can improve energy security, improve the rural environment, and increase rural residents' income $[23,24]$. Moreover, when compared with agricultural residues, the combustion characteristics of briquette biofuel manifest improved combustion efficiency, which means that some of the primary energy can be replaced [23].

The processing of biomass into briquettes is addressed by many experts, for example, Cahyono et al. [25], who explored the potential of using seeds of the tropical fruit durian as a suitable external binding material for briquette production; it is the presence of starch which makes durian seeds a suitable binder for briquette production. In 2013, approximately 760 tons of this fruit was harvested in Indonesia [26].

The use of groundnut shells and bagasse as a suitable feedstock material for briquette production was analyzed by Lubwama and Yiga [27] using cassava and wheat starch as the binders.

Wilaipon [28] explored the use of banana husks for briquette production and their properties, depending on the pressure of the briquetting press. Srivastawa et al. [29] evaluated the use of unprocessed vegetables in the form of briquettes. In their study, they confirmed that the compressed briquettes burn longer than the unpressurized material. These can directly extract value from waste, generate jobs, and avoid the need for additional waste treatment.

Biomass briquettes can be produced from various organic waste materials. However, a problem may arise with the implementation of the technology itself, which is often associated with high initial costs of acquiring a high-pressure briquetting press, with high power consumption required for its operation, and the need for trained personnel $[19,30]$. Modern forms of briquetting technologies are therefore unavailable to most rural populations; nevertheless, it opens the door to modification of such technology and the development of new designs suitable for developing countries and rural areas. Low-pressure briquetting technology provides the relevant alternative to the high-pressure one and represents the topic of many current investigations in Asia and Africa. Such technology works with the same principle of feedstock densification into briquette fuel by using a piston or screw as a pressing unit. However, the difference consists in the briquetting press itself. Low-pressure technology provides many different briquetting press designs (wood, metal, combined); the designs are developed and implemented in specific conditions for specific briquette production (specific feedstock materials, external binders, production parameters) [31-33], resulting in the production of briquette biofuel of different shapes and sizes. Nevertheless, the main difference between the two mentioned briquetting technologies is the level of pressure and need for electricity. Low-pressure briquetting presses operate with a lower level of pressure $(<5 \mathrm{MPa})$ than the high-pressure ones $(>15 \mathrm{MPa})$. In consequence, low-pressure briquetting presses must use external binders for ensuring the briquettes' mechanical quality. Such issues can be easily improved by using wastepaper and cardboard. Most of the previously manufactured low-pressure briquetting presses use only human power; there is thus no need for electricity consumption, a decisive advantage of such technology in rural areas [34] given the fact that rural areas of Java often lack proper access to technologies, knowledge, credit, or electricity, but may have abundant sources of agricultural waste.

Therefore, this study examines the possibility of using the low-pressure briquetting press in rural and peri-urban households of East Java. The primary goal of this study is to determine the potential of utilizing waste biomass processing through the briquetting process, using Malang and Blitar regions as examples.

\section{Materials and Methods}

This study examined the possibility of converting biomass into solid biofuels, which is not only a technology that provides higher efficiency than raw untreated biomass, but it is also a suitable waste management technology [35]. According to Mulyana [6] the following factors should be ensured 
when setting up briquetting technology: (1) availability of biomass to supply the bioenergy plan and market for the biomass-derived product; (2) society's readiness to involve and participate in collecting the biomass and also readiness to be involved in the briquette production process; (3) skilful human resources (biomass technology and briquette production). (4) Financial structure including the cost of money, government subsidy if any, and loan guarantee. (5) Capital and operating cost plan. (6) Study of environmental impact and applicable regulation and the approval process.

Within our study, we consider all six factors, with the main focus on the possibility of using the low-pressure briquetting technology in rural household conditions. Therefore, the study includes an assessment of the current situation concerning biomass production, the existence of a possible market, current knowledge of the society about waste management and briquette production, the current regulation, the interest/willingness of the people to produce briquettes and their financial possibilities. Furthermore, the study also identifies the characteristics of the generation and composition of household solid waste in both research areas.

\subsection{Description of the Study Area and Data Collection}

The study area-eastern Java-has been chosen due to the lack of research focused on this part of the island. Limited research related to briquette production has so far been focused on the potential of west Java.The area of eastern Java is very diverse. Modern cities alternate with agricultural areas, which are often still not electrified. East Java is one of the biggest and most successful provinces of Indonesia in terms of agricultural development [28].

For the sake of comparison, we chose two research areas: the Donowarih village (a rural area), part of the Karangploso district in Malang regency, located on the slope of Mount Arjuna; and the Maron village (a peri-urban area), part of the Kedemangan district in Blitar regency (Figure 1). The Karangploso district is a rural area covered by forest, and in the Donowarih village, people plant mostly rice, corn, cassava, sugarcane, vegetables and oranges [36]. The Maron village is a peri-urban area where farmers mostly plant rice, soybean, coffee and coconuts. The population, as well as the area of both locations, is shown in Table 1 .

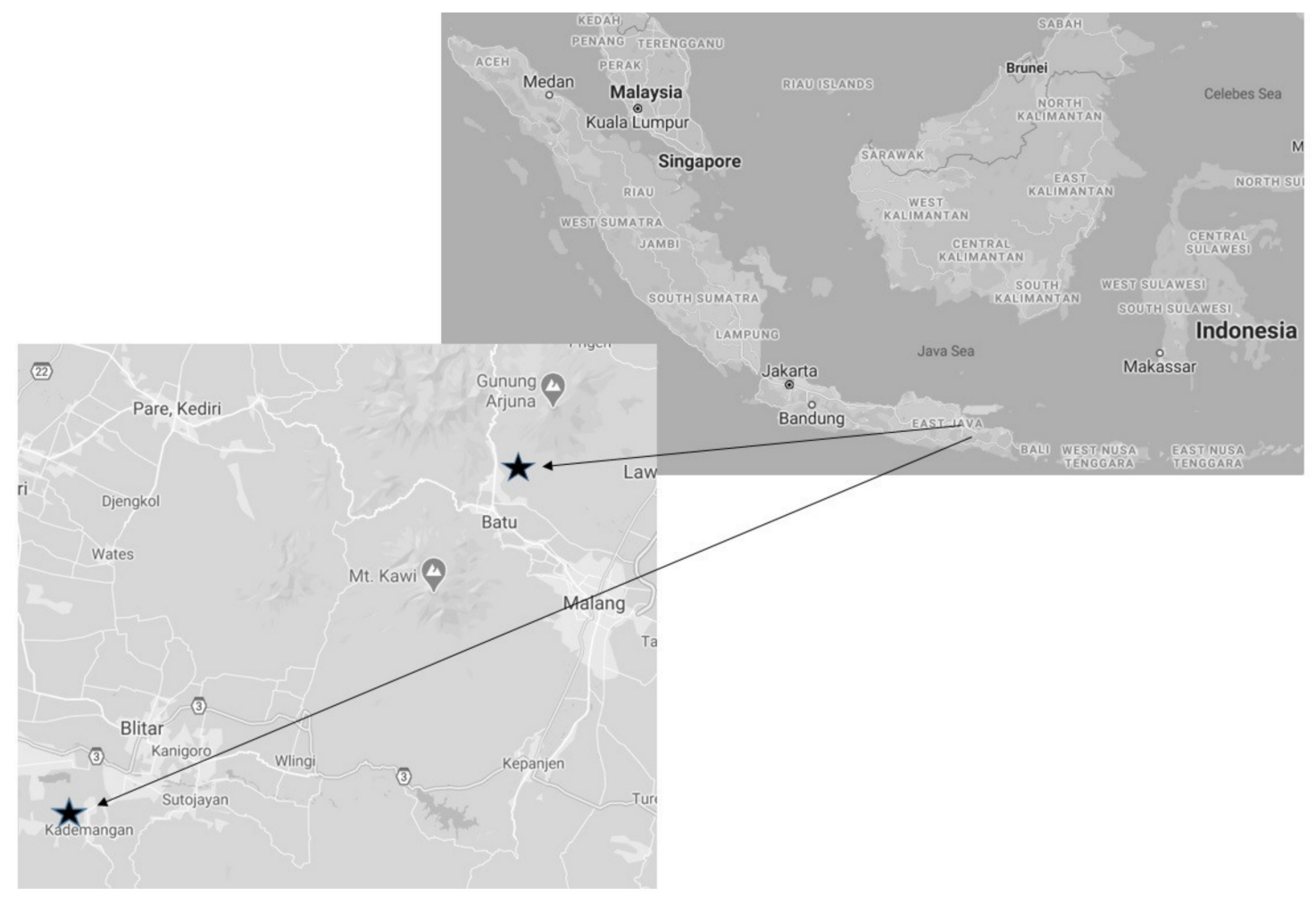

Figure 1. Target area (East Java, Blitar, and Malang regency). Adjusted from: Google maps. 
Table 1. Target area, population. Adjusted from: Badan Pusat Statistics [36,37].

\begin{tabular}{ccc}
\hline Village & Population & Size of the Area \\
\hline Maron & 2979 & $4.63 \mathrm{~km}^{2}[38]$ \\
Donowarih & 10,069 & $12.98 \mathrm{~km}^{2}[37]$ \\
\hline
\end{tabular}

Data for this study were collected at the level of the local population, as well as local authorities (municipal representatives). A mix of quantitative and qualitative methods was exploited, with the latter including questionnaire surveys, interviews, observation, and focus groups. The snowball technique was chosen as an appropriate sampling tool. A questionnaire survey was conducted in both locations during the summer of 2018, with $N=50$ in each location: Village Donowarih (rural area), Malang regency $(N=50)$, and village Maron (peri-urban area), Blitar regency $(N=50)$ areas, East Java, Republic of Indonesia during the summer period 2018. The questionnaires consisted of open, closed, and semi-closed questions and focused on the respondents' socio-economic situation, on technical aspects of waste management, and the main produced waste biomass. The questionnaires were identical for the local population and for the municipal authorities. The data obtained by the questionnaire survey were proceeded by statistical software using descriptive, inferential, and correlation statistics. Interviews, focus group discussions, and observations were conducted after collecting the questionnaires from the respondents. The interviews and focus groups focused on current waste management practices, present energy and biomass sources, knowledge, and sustainable waste treatment methods. Focus groups were conducted in Maron $(N=34)$ as well as in Donowarih $(N=18)$, and they consisted of the description of the briquetting process and, afterwards, in the participants' discussion about this method and its possible application. Data were analyzed quantitatively by descriptive statistical methods, as well as qualitatively by analyzing data obtained from the interviews, observations, and focus groups.

\subsection{Description of the Target Technology}

The low-pressure briquetting technology, which was used as reference technology for the data collection, was represented by a wooden manual low-pressure briquetting press, with the operation pressure below $5 \mathrm{MPa}$. The design of the press was developed in accordance with the requirements and possibilities of the target areas. The press was constructed mainly from wooden components, it was partly dismountable, and required only man-power for pressing of the piston using a single lever. The first main objective was that the potential users (rural population) understood and appreciated the characteristics of the technology and the potential for its use. The second objective concerned the low-cost production of the equipment: construction costs were estimated at USD 10, and the majority of the components are easily replaceable and produced from one log to ensure similar dimensions. Figure 2 shows the scheme of the designed wooden manual low-pressure briquetting press which was used during the presentations.

\subsection{Statistical Analysis}

The collected data were categorized, coded, and analyzed using descriptive, inferential, and correlational analyses (depending on the specific data type) in the statistical software package Statistica 10. Descriptive statistics (mean, distribution, and standard deviation) were calculated to gain an overview of both target groups in terms of their income level, level of education or percentage distribution of household waste, or knowledge of waste treatment methods. T-test was used to discover possible differences between the analyzed groups in their willingness to invest in the technology. Furthermore, the Pearson's correlation coefficient $(R)$ was counted to detect the possible relationship between the respondents' education level and their willingness to invest. 


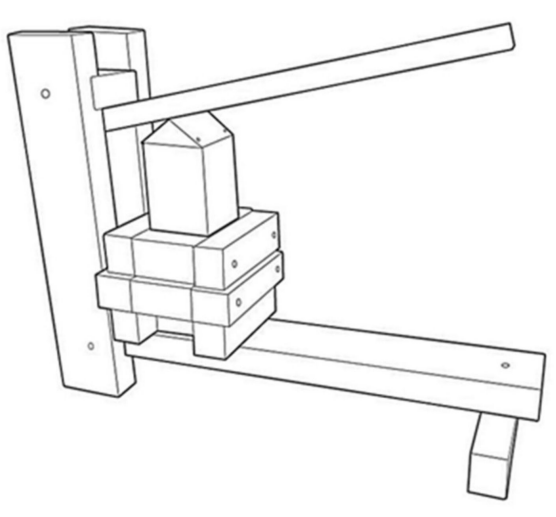

(a)

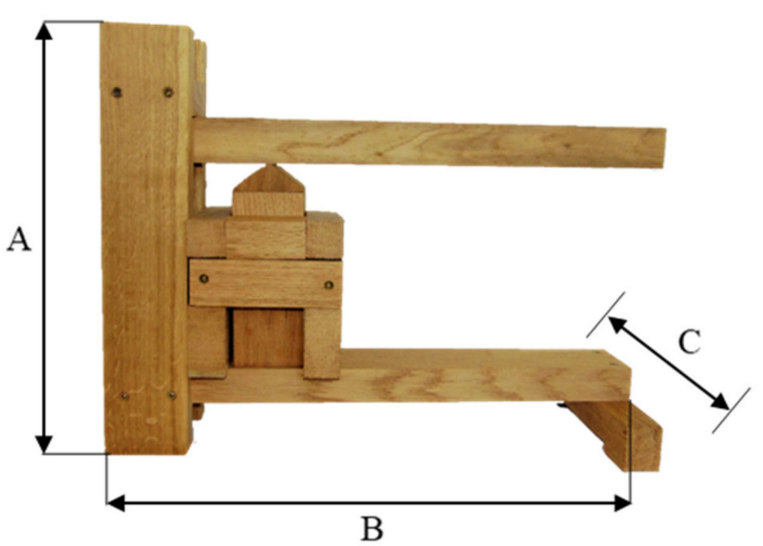

(b)

Figure 2. Presented manual wooden low-pressure briquetting press: (a) scheme; (b) dimensions: $\mathrm{A}=$ $47 \mathrm{~cm}, \mathrm{~B}=61 \mathrm{~cm}, \mathrm{C}=25 \mathrm{~cm}$.

\section{Results and Discussion}

\subsection{Socioeconomic Characteristics of the Target Group}

The interviewed respondents were small-scale farmers living off crop production. In the case of Donowarih (the rural area), it was mainly coffee, chili, or vegetables. More than one-fourth (28\%) of the households also owned small livestock like poultry and goats. Donowarih is part of the protected and research area of the local university (Brawijaya). Nevertheless, despite Brawijaya university research and educational activities, the local people are not fully aware of the necessity of environmental protection. It is also important to note that the Donowarih village is quite far from the main infrastructure of Malang. People mostly use and consume what they plant, so there is still a minimum of plastic trash. Nevertheless, according to the research of Ying Chu Cheng [39], we can expect that the ongoing urbanization will soon change the situation.

In the Donowarih village, illiteracy still partly persists, mostly in the older generation. The majority of the population usually finish elementary school or secondary school. Table 2 compares the average household income per month in the two localities examined in this study. The average household has four family members. The majority of the population is either very young (children) or old (grandparents). Currently, the middle generation of potential new farmers often participates in off-farm short- or long-term activities and the majority have moved to urban areas. The reason is the same as that listed by Corsi and Salvioni [38], namely that, first, off-farm income is usually higher and more stable, and second, that urban areas offer more job opportunities.

Table 2. The income of the household. $N=100$.

\begin{tabular}{cccc}
\hline Village & Mean (USD) & Std. Deviation & Std. Error Mean \\
\hline Maron (peri-urban) & 67.62 & 23.02 & 3.25 \\
Donowarih (rural) & 67.06 & 20.9 & 2.96 \\
\hline
\end{tabular}

In Maron (the peri-urban area), the average household also has four family members. As for the level of education, the lowest education level here is the middle school for 13-15 years old children (SMP-“Sekolah Menengah Pertama"), which is obligatory. Before middle school, children visit the primary school ("Sekolah Dasar"). Most people have finished high school and a few of them possess university degrees as well. Considering the education level, Maron's respondents would be predicted to have a higher income (see Zhang et al. [40]). However, as shown in Table 2, which compares the average household income per month in the two localities, the income in Maron is very similar to 
that in Donowarih households. These results may be influenced by other factors (indebtedness, poor climate conditions, etc.). Besides farming, local people in Maron are often more involved in off-farm activities such as construction works or running of small shops (warungs), which should, according to Wanglin et al. [41], lead to higher income. Nevertheless, the difference in average income is statistically insignificant $(p=0.8986)$.

Age composition in Maron was similar to Donowarih as well, with the same trend of the younger generation leaving their family and moving to cities. Although we found no positive effect of education on income, it has to be noted that education improves the ability to make informed decisions about new inputs in terms of both machinery and fertilizers, and, as a result, it plays an important role for farmers' livelihood.

In both areas, people still use wood as fuel, besides LPG. In the case of Donowarih, wood is still the primary energy source, which is in line with the research of Timko and Kozak [42], who reported the prevalent importance of firewood in developing countries. According to information gained from questionnaires, the price of monthly consumption of LPG is about USD 2. However, in many cases, people still prefer wood because it is "for free". During the rainy season, firewood also serves as a source of heat. In addition, women very often stated that food tastes better if it is cooked on fire than LPG. Importantly, using bio-briquettes could solve this situation because the taste would remain the same. On average, people in both areas spend $7 \mathrm{~h}$ per week gathering firewood.

\subsection{Availability of Biomass and Possible Bio-Briquette Market in Target Areas}

Regarding agriculture development, East Java is one of the biggest and most successful provinces of Indonesia. Between 2014 and 2015 it became a province with the largest rice production in Indonesia (more than 13 million tons harvested in 2015). Besides rice production, around 1/3 of Indonesian corn production also comes from East Java. Furthermore, soya beans, peanuts, or sweet potatoes are well-known agricultural products of this area as well [36]. Table 3 shows examples of biomass with possible further utilization.

Table 3. Availability of biomass in East Java.

\begin{tabular}{ccl}
\hline Biomass & $\begin{array}{c}\text { Production } \\
\text { [T/Year] }\end{array}$ & \multicolumn{1}{c}{ Remarks } \\
\hline Rubberwood & $27,622(2017)$ & $\begin{array}{l}\text { Logs are used as firewood in brick and roof tile industry } \\
\text { Bagasse is generally used in sugar factories (90\%) } \\
\text { Potentially sugar residues (bagasse). The use of cane tops } \\
\text { and leaves needs to be investigated } \\
\text { Potentially rice residues (husks). Stalk and straw are } \\
\text { generated at the field and generally burnt, in some areas } \\
\text { used for feeding or raw material for paper industry, husks } \\
\text { often burnt uncontrolled } \\
\text { Potentially coconut residues (shells). Residues are generated } \\
\text { decentralized and usually left on the plantation field, largely } \\
\text { used as firewood and for the production of charcoal }\end{array}$ \\
\hline Coconut (residues) & $258,142(2017)$ &
\end{tabular}

Adjusted from: BPS [43], Abdullah [44].

Despite the fact that the production of briquettes has a long tradition in West and Middle Java, in East Java the briquettes market has only recently been growing. However, producers are oriented either on export, bigger factories, or on well-secured people from cities who use briquettes only for occasional events (home barbecue, shisha, etc.). In East Java, briquettes are mostly produced from coconut shells. After drying and sifting coconuts, they are efficiently carbonized, crushed, and mixed, and afterwards shaped into the proper size. The market price for $1 \mathrm{~kg}$ of those briquettes available in local shops is about USD 2.80, which is higher price than for LPG for the whole month. Therefore, most people prefer to pay less for the cheaper LPG than to use more expensive briquettes available on the market. Briquettes can also not be purchased at the local market, but only in special stores in malls 
located in larger cities. So far, briquettes constitute a luxury item for most local people. For the reasons mentioned above, $98 \%$ of our respondents did not have any information regarding the existence of those briquettes at the Indonesian market, and no one seriously considers their usage for the current price; briquettes are currently not financially accessible for the majority of local people.

Regarding other waste management methods and biofuel production, $5 \%$ of respondents from Donowarih (the rural area) had information about the production of biogas, which is produced close to their area from the excrements of cows. Currently, they are not interested in this production because they do not possess enough livestock. However, if the situation changes, all of those respondents would like to adopt the technology if it were affordable.

In both locations, there are several poultry houses, and new-born chickens require stable temperature, which is achieved by using gas as a source of heating. As a costly resource, LPG often prevents other farmers from entering the sector. Briquettes from biomass could be one of the solutions that would remove this barrier.

\subsection{Household Waste Management}

Household waste management was an important part of the research. Firstly, it was necessary to analyze the composition of the waste, secondly, people's habits and behavior as well as their knowledge about possible techniques of waste management.

Donowarih is close to the forest and people often use wood as fuel. That is why wooden residues (bark, sawdust, trimmings, split wood) account for $24 \%$ of household waste. Organic waste (kitchen leftovers and agricultural waste) accounts for the largest part. As we can see from Figure 3, inhabitants of Donowarih still do not use any plastics. On average, one household produces $1.5 \mathrm{~kg}$ of waste per day.

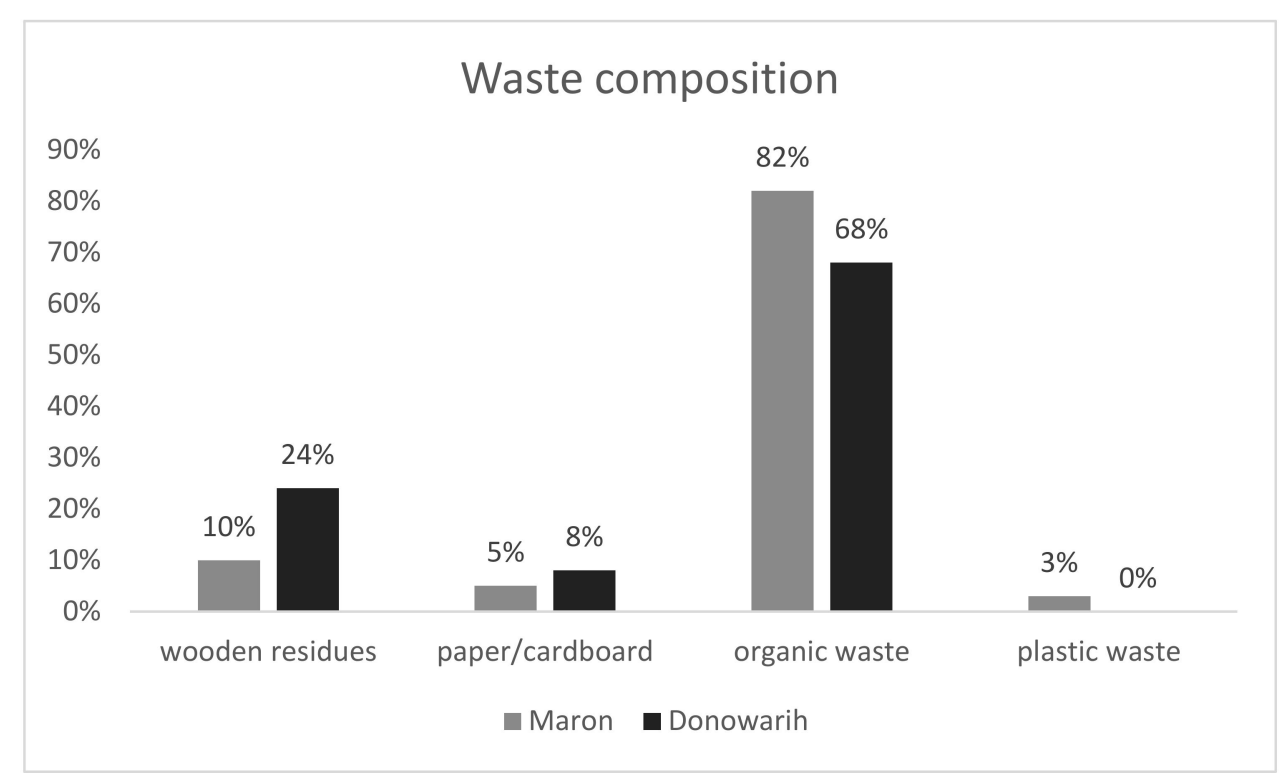

Figure 3. Household waste composition in Maron (peri-urban) and Donowarih (rural).

In the case of Maron (peri-urban area), plastic constitutes a marginal part of household waste. Same as in Donowarih, organic waste forms the majority of waste produced (Figure 3). On average, a household produces $1.8 \mathrm{~kg}$ of waste per day.

Knowledge about waste management is very low in both regions. In the case of Donowarih (rural area), respondents had no information about the sorting of solid waste or recycling. Few of them (about $15 \%$ ) had knowledge about composting. A similar situation was also visible in Maron (peri-urban area), where the majority of people ( $98 \%$ ) did not know anything about recycling or sorting of solid waste; on the other hand, all of them possessed some knowledge about composting. 
In both areas, people use kitchen leftovers even as food for livestock or as composting material. According to Roubík et al. [45], it is possible to utilize kitchen leftovers in biogas production. Biogas technology could provide clean energy in the form of biogas and fertilizer as a by-product in rural areas of Indonesia [46], but the majority of the population disposes of it without any further utilization. In both areas, the most common practice of waste management is open burning.

\subsection{Possibility of Briquette Production-Human Resources, Financial Possibilities, and Capital/Operating Costs}

As described in previous sections, sources of biomass are abundant in both areas. Respondents were interested in the possibility of briquette production and, provided that the initial costs are acceptable, would be willing to invest in the presented manual wooden low-pressure briquetting press. On average, they were also willing to spend $5 \mathrm{~h}$ per week operating the press to produce briquettes. Especially in Maron (peri-urban), people would appreciate the possibility of generating their own energy sources rather than collecting or buying wood. In Donowarih (rural area), the willingness of local people was not as high as in Maron (see Table 4). Due to low public awareness about the possibilities of waste treatment methods, people often distrusted the technology itself and did not believe in its benefits.

Table 4. Willingness to use/produce briquettes. $N=100$.

\begin{tabular}{ccc}
\hline Village & Usage of Briquettes & Production of Briquettes \\
\hline Maron (peri-urban) & $100 \%$ & $96 \%$ \\
Donowarih (rural) & $88 \%$ & $80 \%$ \\
\hline
\end{tabular}

Village authorities of both areas would be willing to invest in introducing low-pressure briquetting technology, and in case of a budget surplus, they would see further possibilities in selling briquettes on the market. Taking into account the estimated price of the press (USD 10), we can claim that in both areas, people are willing to invest a sufficient amount of financial resources required for the press construction. As shown in Table 5, people from Maron (peri-urban area) were willing to invest more into the technology ( \pm 25 USD) in comparison with people from Donowarih $( \pm U S D)$, a significant difference $(p=0.0056)$. Moreover, a moderate positive correlation was found between the level of education and the willingness to invest in the technology. Thus, a higher level of education meant also a higher level of investments and vice versa $(R=0.5146 ; p=0.000681)$.

Table 5. Willingness to invest in technology. $N=100$.

\begin{tabular}{cccc}
\hline Village & Mean (USD) & Std. Deviation & Std. Error Mean \\
\hline Maron (peri-urban) & 24.92 & 1.54 & 2.19 \\
Donowarih (rural) & 18.25 & 6.10 & 0.86 \\
\hline
\end{tabular}

Apart from using briquettes to cover the needs of the involved households, they could also substitute coal in restaurants/warungs or in households from adjacent areas. On a larger scale, briquettes could be used as a source of heat in poultry farming. Currently, small-scale farmers find it difficult to open their own poultry farm due to the necessity of intensive heating, which they cannot afford. Producing briquettes on their own could open access to the market also for these farmers. Tucho and Nonhebel [47] studied the potential of using efficient technologies (briquetting, biogas production) in Ethiopian rural areas. Energy conversion technologies can help in some cases to achieve biomass savings of up to $50 \%$. This, however, depends on various characteristics of the household (number of animals, available land, etc.).

According market study [48], briquette production has the potential to become successful in the local market. Positive examples have been documented in the Asian region, such as Cambodian Sustainable Green Fuel Enterprise (SGFE) or Indian Biomass Urja Kotdwar. 


\subsection{Environmental Impact, Applicable Regulation, and the Approval Process}

According to $\mathrm{Hu}$ et al. [23], the usage of agricultural residues in the form of briquettes can improve the rural environment, secure forest resources, and increase the income of local people. Especially in Donowarih (rural area), where people still use mostly firewood as the primary energy source and where residues from agriculture as well as from household waste are abundant, briquette production could positively contribute to the preservation of the local environment (especially forest resources) and ensure energy security (compare the study by Martinez et al. [49] on Brazil). Even though the Maron village is located in the peri-urban area and people mostly use gas as the primary source of energy, the usage of briquettes can reduce the amount of waste as well as increase household income.

As mentioned before, oil and gas reserves in Indonesia are decreasing [3], and the Indonesian government is therefore looking for suitable alternatives. Besides the coal industry, the government is targeting abundant sources of energy, with biomass among them. As this solution can strengthen energy security and also reduce emissions, the utilization of bioenergy has become an important part of the Indonesian national energy policy; Governmental Regulation No 047/2006 [50] on the domestic production of briquettes from coal and biomass is most relevant. The annexes to the Regulation specify the permitted air pollutant concentration values. Another one is the Regulation No 150/2000 [51] on the usage of land for biomass production, which states that every area must follow its regulation specified by the Governor/Regents or Mayor. In the case of large-scale production, both villages must therefore follow regulations of the Malang region. The production of electricity from the biomass/waste should adhere to Regulation No 53/2018 [52].

There are multiple governmental programs which support the utilization of sustainable biomass and offer benefits for producers, such as VAT exemption, investment tax incentives, direct subsidy on retail price for the transportation sector, interest rate subsidy for biofuel feedstock plantations, and simplification of license procedures. Moreover, multiple governmental funds are available, such as the Indonesia Biofuel Program, the Clean Technology Fund, the Indonesia Climate Change Trust Fund, or the Income Tax Facility [53,54].

\section{Conclusions}

According to the results of the study, both areas have significant potential for biomass utilization and its conversion into briquettes by using low-pressure briquetting technology. Currently, there is a market with manufactured coconut briquettes in both research areas. Nevertheless, those briquettes are costly and not easily accessible for the local population. In addition, only $2 \%$ of all respondents were familiar with this product. Even though higher biomass production can be seen in the rural area (Donowarih), a higher interest in low-pressure briquetting technology was documented in the peri-urban (Maron). Besides this, locals are willing to invest more in Maron than in Donowarih. The reason for higher investment willingness may be explained by the level of education, as shown by the moderate positive correlation. The population in Donowarih has not yet encountered briquetting, and the interest in investing in the input and operating costs is thus minimal. In the case of rural lowland areas around Blitar, the proportion of organic household waste material was lower. Possibilities for utilizing agricultural waste also exist in this area, especially rice waste material. There was a higher interest in the given method than in the mountain areas, while at the same time people were willing to invest more in the technology. Currently, Indonesia is following the trend in sustainable energy production. Unfortunately, the knowledge of this among the rural population is low. Therefore, awareness-raising activities are needed to spread ecological waste management practices, so as to increase their interest in them. Further research is recommended for the application of low-pressure briquetting technology in order to find a suitable composition of briquettes after the installation of wooden manual low-pressure briquetting press.

Author Contributions: Conceptualization, H.R.; methodology, P.F., A.B. and H.R.; validation, P.F.; formal analysis, P.F., A.B. and H.R.; investigation and data collection, P.F.; resources, A.B. and H.R.; data curation, P.F. and 
H.R.; writing - original draft preparation, P.F., A.B. and H.R.; writing—review and editing, P.F., A.B. and H.R.; visualization, P.F.; supervision, H.R.; project administration, A.B. and H.R.; funding acquisition, A.B. and H.R. All authors have read and agreed to the published version of the manuscript.

Funding: The performed research was funded by the EUROPEAN UNION (EU), the managing authority of the Czech Operational Programme Research, Development and Education within the project "Supporting the development of international mobility of research staff at CULS Prague", reg. no. CZ.02.2.69/0.0/0.0/16_027/0008366. These and the Reference headings are in bold but have no numbers. Furthermore, research was supported by the Internal Grant Agency of the Czech University Life Sciences Prague 20173005 (31140/1313/3108) and by Internal Grant Agency of the Faculty of Engineering, Czech University of Life Sciences Prague named "The energy intensity of the compaction process in the production of briquettes from waste materials with a focus on waste biomass in the small-scale production". In addition, it was supported by the Internal Grant Agency of the Faculty of Tropical AgriSciences, Czech University of Life Sciences Prague, project number (20205008).

Conflicts of Interest: The authors declare no conflict of interest. The funders had no role in the design of the study; in the collection, analyses, or interpretation of data; in the writing of the manuscript, or in the decision to publish the results.

\section{References}

1. Demirbaş, A. Potential applications of renewable energy sources, biomass combustion problems in boiler power systems and combustion related environmental issues. Prog. Energy Combust. Sci. 2005, 171-192, 437-445. [CrossRef]

2. BPS. Sensus Penduduk 2010. Badan Pusat Statistik. 2010. Available online: http://sp2010.bps.go.id/ (accessed on 10 January 2018).

3. Member Countries. OPEC. 2018. Available online: http://www.opec.org/opec_web/en/about_us/25.htm (accessed on 6 January 2019).

4. Juniah, R.; Rinaldy, D.; Suparmoko, M.; Sarwanto Moersidik, S.; Waristian, H. Environmental value losses as impacts of natural resources utilization of in coal open mining. MATEC Web Conf. 2017, 101, 04013. Available online: http://www.matec-conferences.org/10.1051/matecconf/201710104013 (accessed on 2 October 2020). [CrossRef]

5. Presidential Regulation No. 5/2006. Available online: http://extwprlegs1.fao.org/docs/pdf/ins64284.pdf (accessed on 2 October 2020).

6. Mulyana, C.; Fitriani, N.I.; Saad, A.; Yuliah, Y. Empowerment model of biomass in west java. IOP Conf. Ser. Earth Environ. Sci. 2017, 65, 012016. Available online: http://stacks.iop.org/1755-1315/65/i=1/a=012016?key= crossref.9ba397e60e19145973e97da147fd83a2 (accessed on 2 October 2020). [CrossRef]

7. Putrasari, Y.; Praptijanto, A.; Santoso, W.B.; Lim, O. Resources, policy, and research activities of biofuel in Indonesia: A review. Energy Rep. 2016, 2, 237-245. [CrossRef]

8. McDonald, G.; Rahmanulloh, A. Indonesia Biofuels Annual. 2018. Available online: https://apps.fas.usda.gov/newgainapi/api/report/downloadreportbyfilename?filename=biofuels $\%$ 20annual_jakarta_indonesia_8-13-2018.pdf (accessed on 2 October 2020).

9. Azhar, B.; Saadunb, N.; Prideauxc, M.; Lindenmayerd, B. The global palm oil sector must change to save biodiversity and improve food security in the tropics. J. Environ. Manag. 2017, 203, 457-466. [CrossRef]

10. Nurlaila, I.; Yuliar, S.; Amir, R. Multicultural in Indonesia's biofuel innovation initiative: Critical issues of land use and sustainable environment. Soc. Behav. Sci. 2012, 35, 697-704. [CrossRef]

11. Maniatis, K.; Vanhille, S.; Martawijaya, A.; Buekens, A. Solid waste management in Indonesia: Status and potential. Resour. Conserv. 1987, 2000, 277-290. [CrossRef]

12. Suherman, V.S.; Franco-García, M.L.; Abdoellah, O.S.; Kurniadie, D.; Hidayati, Y.A. Circularity of wastes: Stakeholders identity and salience for household solid waste management in Cimahi City, West Java Province, Indonesia. In Towards Zero Waste. Greening of Industry Networks Studies; Franco-García, M.L., Carpio-Aguilar, J., Bressers, H., Eds.; Springer: Cham, Switzerland, 2019; Volume 6. [CrossRef]

13. Sudarningsih, S.; Bijaksana, S.; Ramdani, R.; Hafidz, A.; Pratama, A.; Widodo, W.; Iskandar, I.; Darharta, D. Variations in the concentration of magnetic minerals and heavy metals in suspended sediments from Citarum river and its tributaries, West Java, Indonesia. Geosciences 2017, 7, 66-72. Available online: http://www.mdpi.com/2076-3263/7/3/66 (accessed on 2 October 2020). [CrossRef] 
14. Sunowo, A. Indonesia's Potential Contribution of Biomass in Sustainable Energy Development. Bandung Institute of Technology. 2016. Available online: https://www.jstage.jst.go.jp/article/apcche/2004/0/2004_0_8/ _pdf. (accessed on 2 October 2020).

15. Permana, S.A.; Towolioe, S.; Aziz, N.A.; Ho, C.S. Sustainable solid waste management practices and perceived cleanliness in a low income city. Habitat Int. 2015, 49, 197-205. [CrossRef]

16. Sudibyo, H.; Majid, A.I.; Pradana, Y.S.; Budhijanto, W.; Deendarlianto. Technological evaluation of municipal solid waste management system in Indonesia. Energy Procedia 2017, 105, 263-269. [CrossRef]

17. Anshar, M.; Ani, F.N.; Kader, A.S. The energy potential of municipal solid waste for power generation in Indonesia. J. Mek. 2014, 37, 42-54. Available online: https://mech.utm.my/wp-content/uploads/2017/01/06_ The-Energy-Potential-of-Municipal-Solid-Waste-for-Power-Plants-in-Indonesia.pdf. (accessed on 2 October 2020).

18. Ghosh, P.; Shaha, G.; Chandra, R.; Sahota, S.; Kumur, H.; Vijay, V.K.; Thakur, I.S. Assessment of methane emissions and energy recovery potential from the municipal solid waste landfills of Delhi, India. Bioresour. Technol. 2019, 272, 611-615. [CrossRef] [PubMed]

19. Kaygusuz, K. Energy for sustainable development: A case of developing countries. Renew. Sustain. Energy Rev. 2012, 16, 1116-1126. Available online: http://inkinghub.elsevier.com/retrieve/pii/S1364032111005491 (accessed on 2 October 2020). [CrossRef]

20. Permadi, D.A.; Oanh, N.T.K. Assessment of biomass open burning emissions in Indonesia and potential climate forcing impact. Atmos. Environ. 2013, 78, 250-258. Available online: http://linkinghub.elsevier.com/ retrieve/pii/S1352231012009806 (accessed on 2 October 2020). [CrossRef]

21. Prastowo, B. Biomass Resource in Indonesia: Indonesia s Solid Biomass Energy Potential. 2012. Available online: https://biomassourlastresource.files.wordpress.com/2012/03/d1-03-biomass-resource-inindonesia-2011-itb-final-pdf-bambang-prastowo.pdf (accessed on 6 January 2019).

22. Krishna, V.V.; Kubitza, C.H.; Pascual, U.; Qaim, M. Land markets, property rights, and deforestation: Insights from Indonesia. World Dev. 2017, 99, 335-349. [CrossRef]

23. Hu, J.; Lei, T.; Wang, Z.; Yan, X.; Shi, X.; Li, Z.; He, X.; Zhang, Q. Economic, environmental and social assessment of briquette fuel from agricultural residues in China-A study on flat die briquetting using corn stalk. Energy 2014, 64, 557-566. [CrossRef]

24. Shahapur, A.; Desai, N.M.; Kader, A. Agricultural wastes as a supplementary source of energy: An economic assessment of a briquette making facility. J. S. Pac. Agric. 2017, 20, 25-33.

25. Cahyono Rochim, B.; Santoso, J.; Miliati, R. Biomass briquettes using Indonesia Durian seeds as binder agent: The effect of binder concentration on the briquettes properties. Chem. Eng. Trans. 2017, 56, 1663-1668. [CrossRef]

26. Soesilowati, E.; Dian Wisaka, P.S.; Salleh, M. Strategic policies for increasing the competitive powers of Indonesian horticultural products in Asean markets. Pertanika J. Soc. Sci. Humanit. 2016, 24, 95-110.

27. Lubwama, M.; Yiga, V.A. Development of groundnut shells and bagasse briquettes as sustainable fuel sources for domestic cooking applications in Uganda. Renew. Energy 2017, 111, 532-542. Available online: http://linkinghub.elsevier.com/retrieve/pii/S0960148117303488 (accessed on 2 October 2020). [CrossRef]

28. Wilaipon, P. The effects of briquetting pressure on banana-peel briquette and the banana waste in northern Thailand. Am. J. Appl. Sci. 2009, 6, 167-171. Available online: http://www.thescipub.com/abstract/?doi= ajassp.2009.167.171 (accessed on 2 October 2020). [CrossRef]

29. Srivastava, N.S.L.; Narnaware, S.L.; Makwana, J.P.; Singh, S.N.; Vahora, S. Investigating the energy use of vegetable market waste by briquetting. Renew. Energy 2014, 68, 270-275. Available online: http://linkinghub.elsevier.com/retrieve/pii/S0960148114000779 (accessed on 2 October 2020). [CrossRef]

30. Lohri, C.R.; Sweeney, D.; Rajabu, H.M. Carbonizing Urban Biowaste for Low-Cost Char Production in Developing Countries-A Review of Knowledge, Practices and Technologies; Joint Report by Eawag, MIT D-Lab and UDSM; Eawag: Dübendorf, Switzerland; MIT D-Lab: Cambridge, MA, USA; UDSM: Dar es Salaam, Tanzania, 2015.

31. Abakr, Y.A.; Abasaeed, A.E. Experimental evaluation of a conical screw briquetting machine for the briquetting of carbonized cotton stalks in Sudan. J. Eng. Sci. Technol. 2006, 1, 212-220.

32. Ngusale, G.; Luo, Y.; Kiplagat, J. Briquette making in Kenya: Nairobi and peri-urban areas. Renew. Sustain. Energy Rev. 2014, 40, 749-759. [CrossRef]

33. Yank, A.; Ngadi, M.; Kok, R. Physical properties of rice husk and bran briquettes under low pressure densification for rural applications. Biomass Bioenergy 2016, 84, 22-30. [CrossRef] 
34. Stanley, R. Fuel Briquettes-Theory and Applications from Around the World; Legacy Foundation: Hainesport, NJ, USA, 2003.

35. Mwampamba, T.H.; Owen, M.; Pigaht, M. Opportunities, challenges and way forward for the charcoal briquette industry in Sub-Saharan Africa. Energy Sustain. Dev. 2013, 17, 158-170. Available online: http://linkinghub.elsevier.com/retrieve/pii/S0973082612000750 (accessed on 2 October 2020). [CrossRef]

36. BPS. Kacamatan Karangploso Dalam Angka 2018. Badan Pusat Statistik. 2018. Available online: https://malangkab.bps.go.id/publication/2018/09/26/aca18492f30b99950ab7f07f/kecamatan-karangplosodalam-angka-2018.html (accessed on 10 January 2019).

37. BPS. Provinsi Java Timur Dalam Angka 2020. Badan Pusat Statistik Statistik. 2020. Available online: https:/jatim.bps.go.id/publication/2020/05/19/6225e5df323aa13d4fb1e4f4/provinsi-jawatimur-dalam-angka-2020.html (accessed on 4 January 2020).

38. Corsi, A.; Salvioni, C. Once part-timer always part-timer? Causes for persistence in off farm work state of farmers. Bio Based Appl. Econ. 2017, 6, 159-182. [CrossRef]

39. Chu Cheng, Y. Effects of urbanization on municipal solid waste composition. Waste Manag. 2018, 79, 828-836. Available online: https://www.sciencedirect.com/science/article/pii/S0956053X18302356?via\% 3Dihub (accessed on 2 October 2020). [CrossRef]

40. Zhang, J.; Zuo, F.; Zhou, Y.; Zhai, M.; Lin Mei, F.; Cheng, Y. Analyzing influencing factors of rural poverty in typical poverty areas of Hainan Province: A case study of Lingao county. Chin. Geogr. Sci. 2018, 28, 1061-1076. Available online: http://link.springer.com/10.1007/s11769-018-1008-9f (accessed on 2 October 2020). [CrossRef]

41. Wanglin, M.; Zou, X.; Alan, R. Impact of off-farm income on household energy expenditures in China: Implications for rural energy transition. Energy Policy 2019, 127, 248-258. [CrossRef]

42. Timko Joeleen, A.; Kozak, R.A. The influence of an improved firewood cookstove, Chitetzo mbaula, on tree species preference in Malawi. Energy Sustain. Dev. 2016, 33, 53-60. [CrossRef]

43. BPS. Tabel Dinamis Subjek Perkebunan. Badan Pusat Statistik Statisti. 2018. Available online: https: //jatim.bps.go.id/subject/54/perkebunan.html\#subjekViewTab5 (accessed on 9 April 2020).

44. Abdullah, K. Biomass Energy Potentials and Utilization in Indonesia; IPB: Bogor, Indonesia, 2006.

45. Roubík, H.; Mazancová, J.; Heller, T.; Brunerová, A.; Herák, D. Biogas as a promising energy source for Sumatra (review). In Proceedings of the 6th International Conference on Trends in Agricultural Engineering, Prague, Czech Republic, 7-9 September 2016.

46. Roubík, H.; Mazancová, J. Suitability of small-scale biogas systems based on livestock manure for the rural areas of Sumatra. Environ. Dev. 2020, 33, 100505. [CrossRef]

47. Tucho, G.T.; Nonhebel, S. Bio-Wastes as an alternative household cooking energy source in Ethiopia. Energies 2015, 8, 9565-9583. [CrossRef]

48. Green Energy Technologies, 2017. Indonesian Market Study. Available online: https://www.eu-gateway.eu/ about/documents/green-energy-technologies-indonesia-market-study-2017. (accessed on 2 October 2020).

49. Martinez, C.L.M.; Semyagina, E.; de Carneiro, A.C.O.; Vakkilainen, E.; Cardoso, M. Production and characterization of coffee-pine wood residue briquettes as an alternative fuel for local firing systems in Brazil. Biomass Bioenergy 2019, 123, 70-77. [CrossRef]

50. Governmental Regulation No 047/2006. Available online: https://jdih.esdm.go.id/peraturan/permen-esdm47-2006.pdf. (accessed on 2 October 2020).

51. Governmental Regulation No 150/2000. Available online: https://www.hukumonline.com/pusatdata/detail/ 241/node/547/peraturan-pemerintah-nomor-150-tahun-2000. (accessed on 2 October 2020).

52. Governmental Regulation No 53/2018. Available online: https://jdih.esdm.go.id/peraturan/26_Permen\% 20ESDM\%20No.\%2050\%20Tahun\%202018\%20tentang\%20Perubahan\%20atas\%20Permen\%20ESDM\% 20Nomor\%2025\%20Tahun\%202018.pdf. (accessed on 2 October 2020). 
53. Pillai, G.M. Indonesia National Sustainable Energy Strategy Report: Enabling Environment and Technology Innovation Ecosystem for Affordable Sustainable Energy Options. 2014. Available online: https:/www.unescap.org/sites/default/files/Indonesia\%20National\%20Sustainable\% 20Energy\%20Strategy\%20Report.PDF (accessed on 7 September 2020).

54. Kharina, A.; Malins, C.; Searle, S. Biofuels Policy in Indonesia: Overview and Status Report. 2016. Available online: https://heicct.org/sites/default/files/publications/Indonesia\%20Biofuels\%20Policy_ICCT_ 08082016.pdf (accessed on 7 September 2020).

(C) 2020 by the authors. Licensee MDPI, Basel, Switzerland. This article is an open access article distributed under the terms and conditions of the Creative Commons Attribution (CC BY) license (http://creativecommons.org/licenses/by/4.0/). 